\title{
Meningoencephalitis in farmed monosex Nile tilapia (Oreochromis niloticus L.) caused by Streptococcus agalactiae
}

\author{
Harresh Adikesavalu, Sayani Banerjee, Avijit Patra, Thangapalam Jawahar Abraham
}

Received - 13 March 2016/Accepted - 01 August 2017. Published online: 30 September 2017; @Inland Fisheries Institute in Olsztyn, Poland Citation: Adikesavalu H., Banerjee S., Patra A., Abraham T.J. 2017 - Meningoencephalitis in farmed monosex Nile tilapia (Oreochromis niloticus L.) caused by Streptococcus agalactiae - Arch. Pol. Fish. 25: 187-200.

\begin{abstract}
Aquaculture of tilapia is a new research venture in India. With intensification in farming practices, tilapia are increasingly susceptible to bacterial infections. This article describes the isolation and identification of pathogenic bacteria from cultured monosex Nile tilapia, Oreochromis niloticus (L.), that experienced moderate to severe mortalities in West Bengal, India between September and August 2014 and histopathological alterations in various organs. Gram-positive diplococci, identified as Streptococcus agalactiae with Streptococcus identification kits and 16S rDNA sequencing analysis, were isolated from the brain, operculum, and kidney. Other bacteria from the kidney were identified as Aeromonas sobria, A. caviae, Klebsiella pneumoniae ssp. pneumoniae, Escherichia coli, and Enterobacter cloacae. Staphylococcus epidermis was isolated from opercular hemorrhages. Histological sections of the infected tilapia brain revealed meningoencephalitis and granulomatous lesions. Sections from other organs indicated congestion, hemorrhagic and hyperplastic cells, necrosis, vacuolation, hemosiderin deposition, hypertrophic nuclei, melanomacrophage aggregation, and ruptured veins. This report is the first description of $S$. agalactiae as a primary pathogen causing meningoencephalitis in cultured tilapia in India.
\end{abstract}

Keywords: Monosex tilapia, Oreochromis niloticus, Streptococcus agalactiae, Meningoencephalitis, Granulomatous lesions

H. Adikesavalu, S. Banerjee, A. Patra, T.J. Abraham [ $\vdots]$

Department of Aquatic Animal Health, Faculty of Fishery Sciences, West Bengal University of Animal and Fishery Sciences, Chakgaria, Kolkata- 700094, West Bengal, India

e-mail: abrahamtj1@gmail.com

\section{Introduction}

Tilapia is one of the most important cultured fish in many tropical and subtropical countries. Rapid growth rate, high tolerance to adverse environmental conditions, efficient feed conversion, ease of spawning, resistance to disease, and good consumer acceptance make it a suitable fish for culture (Fitzsimmons et al. 2011). The intensification of tilapia farming practices for massive production has, in turn, induced stress and increased their susceptibility to diseases (Klesius et al. 2008). The most common bacterial pathogens of tilapia include Flavobacterium columnare, Aeromonas hydrophila, Edwardsiella tarda, and Streptococcus spp. Among parasites, Ichthyophthirius multifiliis and Trichodina sp. are the most common (Klesius et al. 2008). Streptococcal infection has been reported to cause morbidity and mortality worldwide with an estimated loss of about 250 million USD annually (Klesius et al. 2008). Streptococcal infection in tilapia is caused by Streptococcus iniae, S. agalactiae, S. dysgalactiae, and Lactococcus garvieae (Evans et al. 2006a). Streptococcus agalactiae is also known as a group B streptococcus (GBS) because it is the only streptococcal species that corresponds to serogroup B of the Lancefield Streptococcus. This bacterium has a broad host range and is pathogenic to humans, cattle, and fish (Evans et al. 2002). In humans, S. agalactiae is primarily

\footnotetext{
(c) Copyright by Stanisław Sakowicz Inland Fisheries Institute in Olsztyn.

(C) 2017 Author(s). This is an open access article licensed under the Creative Commons Attribution-NonCommercial-NoDerivs License (http://creativecommons.org/licenses/by-nc-nd/3.0/).
} 
a commensal bacterium of the gastrointestinal and genitourinary tracts, and it causes neonatal meningitis and sepsis. In cattle, it is considered an obligate parasite of the ruminant mammary gland epithelium and causes mastitis (Evans et al. 2002). It causes meningoencephalitis in fish (Zamri-Saad et al. 2010).

Since the first report of GBS in hatchery-reared freshwater fish in the United States in 1966 (Robinson and Meyer 1966), reports of piscine GBS have increased. Piscine GBS, like human and bovine GBS, is found worldwide and affects a variety of freshwater and marine fish under a broad spectrum of environmental conditions (Evans et al. 2008). Clinical signs of $S$. agalactiae infection include lethargy or excitability, going off feed, “C”-shaped body posturing, erratic swimming and whirling, opercular clearing, spinal curvature, and death (Evans et al. 2006a). It is common for $S$. agalactiae to cause diseases in different species of tilapia such as Nile tilapia, O. niloticus (Li et al. 2013, Wang et al. 2013), red tilapia, Oreochromis sp. (Suanyuk et al. 2008, Zamri-Saad et al. 2010, Abuseliane et al. 2011), and red hybrid tilapia, Oreochromis sp. (Alsaid et al. 2013) cultured worldwide, with red tilapia being the most susceptible (Hernandez et al. 2009). In China, large-scale $S$. agalactiae disease outbreaks have had a devastating effect on the development of tilapia aquaculture since 2009, resulting in direct economic losses of about 0.4 billion USD in 2011 (Chen et al. 2012). S. agalactiae infection has not yet been reported in India. In the present study, we report the surveillance isolation, and phenotypic and molecular characterization of the $S$. agalactiae as a primary pathogen causing meningoencephalitis in farmed monosex $O$. niloticus, in West Bengal, India. Histological alterations in various tissues of naturally infected tilapia were also described.

\section{Materials and methods}

\section{Isolation and phenotypic characterization of bacterial strains from monosex Nile tilapia}

Between August 2014 and September 2014, moderate to severe mortalities were observed in cultured monosex O. niloticus in Sonarpur block, South 24
Parganas district, West Bengal, India. The morbid sub-adult monosex Nile tilapia of about $60.0 \mathrm{~g}$ weight and 18-20 cm length with typical symptoms of focal cutaneous hemorrhages from two affected grow-out ponds of 0.25 ha each in Pratapnagar (22 $27^{\prime} 31.8^{\prime \prime} \mathrm{N}$; $88^{\circ} 28^{\prime} 56.9^{\prime \prime}$ E) were examined in September as per standard protocols (OIE 2013). The ponds were stocked with monosex Nile tilapia in early July 2014 at a density of 40,000 individuals per pond $\left(16 \mathrm{~m}^{3}\right)$. The stock size was about 1.20-1.45 g. The total fish biomass in each pond at the time of stocking was $55 \mathrm{~kg}$. Initially, no typical external signs of disease were noticed by the farmer, but 2-4 dead fish were recorded daily in early August. The farmer applied 20 $\mathrm{kg}$ each of solar salt (sodium chloride, $\mathrm{NaCl}$ ) and lime per pond initially, but the mortality continued to occur. Subsequently, treatment with a 10\% enrofloxacin solution at $3 \mathrm{~mL} \mathrm{~kg}^{-1}$ feed for only three days was attempted, but without success. The mortality rate increased with days of culture and about 10-12\% fish died daily in mid-September 2014. The cumulative mortality by late September was about $55-70 \%$.

At the site, behavioral abnormalities and gross and clinical signs of diseased tilapia were recorded on 17.09.2014. Morbid O. niloticus with typical disease symptoms $(n=10)$ from a severely affected pond as well as apparently healthy fish $(n=5)$ from the moderately affected pond were brought to the laboratory in separate oxygen filled polyethylene bags for bacteriological analysis. Prior to bacteriology, the morbid ( $n=4)$ and apparently healthy $(n=3)$ fish were first rinsed with sterile saline, wiped the adhering saline with sterile paper towels and dissected aseptically. Inocula from the brain, hemorrhagic areas of the inner and outer side of operculum, and kidney were aseptically collected, streaked onto brain heart infusion agar (BHIA), glutamate starch phenol red agar supplemented with penicillin G sodium salt, $100 \mathrm{IU} \mathrm{mL}^{-1}$ (GSPA), and Rimler-Shotts agar (RSA) plates (HiMedia 2009) and incubated at $35 \pm 2^{\circ} \mathrm{C}$ for $24-48 \mathrm{~h}$. Based on dominance and definite colony morphology, a total of 11 isolates (six white colonies from BHIA, two yellow colonies from GSPA, and three green colonies with black centers from RSA) were picked, purified by repeated 
Table 1

Surveillance of diseases of cultured tilapia in West Bengal, India between 2012 and 2015 as per OIE (2013)

\begin{tabular}{|c|c|c|c|c|c|c|c|c|}
\hline Cases & Species & $\begin{array}{l}\text { Sampling } \\
\text { period }\end{array}$ & Location & Latitude & Longitude & $\begin{array}{l}\text { Gross and } \\
\text { clinical signs }\end{array}$ & $\begin{array}{l}\text { Mortality } \\
(\%)\end{array}$ & Diagnosis \\
\hline 1 & O. niloticus & May 2012 & Bamanghata & $22^{\circ} 30^{\prime} 01^{\prime \prime} \mathrm{N}$ & $88^{\circ} 29^{\prime} 04^{\prime \prime} \mathrm{E}$ & A & 45 & $\begin{array}{l}\text { Streptococcal } \\
\text { infection* } \\
\text { Streptococcal }\end{array}$ \\
\hline 2 & O. niloticus & June 2012 & Haripota & $22^{\circ} 30^{\prime} 06^{\prime \prime} \mathrm{N}$ & $88^{\circ} 29^{\prime} 20^{\prime \prime} \mathrm{E}$ & A & 40 & $\begin{array}{l}\text { infection* } \\
\text { Streptococcal }\end{array}$ \\
\hline 3 & O. niloticus & August 2012 & Haripota & $22^{\circ} 29^{\prime} 36^{\prime \prime} \mathrm{N}$ & $88^{\circ} 29^{\prime} 36^{\prime \prime} \mathrm{E}$ & $\begin{array}{l}\text { A } \\
\text { Haemorrhagic }\end{array}$ & 20 & infection* \\
\hline 4 & O. mossambicus & February 2013 & Bantala & $22^{\circ} 31^{\prime} 36^{\prime \prime} \mathrm{N}$ & $88^{\circ} 26^{\prime} 22^{\prime \prime} \mathrm{E}$ & spots on body & 2 & $\begin{array}{l}\text { Aeromoniasis } \\
\text { Streptococcal }\end{array}$ \\
\hline 5 & O. niloticus & June 2013 & Nasibur & $22^{\circ} 49^{\prime} 00^{\prime \prime} \mathrm{N}$ & $88^{\circ} 14^{\prime} 51^{\prime \prime} \mathrm{E}$ & A & 38 & $\begin{array}{l}\text { infection* } \\
\text { Streptococcal }\end{array}$ \\
\hline 6 & O. niloticus & July 2013 & Diara & $22^{\circ} 47^{\prime} 25^{\prime \prime} \mathrm{N}$ & $88^{\circ} 17^{\prime} 55^{\prime \prime} \mathrm{E}$ & A & 40 & $\begin{array}{l}\text { infection* } \\
\text { Streptococcal }\end{array}$ \\
\hline 7 & O. niloticus & July 2013 & Naihati & $22^{\circ} 53^{\prime} 58^{\prime \prime} \mathrm{N}$ & $88^{\circ} 26^{\prime} 01^{\prime \prime} \mathrm{E}$ & A & 40 & $\begin{array}{l}\text { infection* } \\
\text { Streptococcal }\end{array}$ \\
\hline 8 & O. niloticus & July 2013 & Haripota & $22^{\circ} 30^{\prime} 01^{\prime \prime} \mathrm{N}$ & $88^{\circ} 29^{\prime} 04^{\prime \prime} \mathrm{E}$ & $\begin{array}{l}\text { A } \\
\text { Stunted }\end{array}$ & 22 & $\begin{array}{l}\text { infection* } \\
\text { Growth }\end{array}$ \\
\hline 9 & O. mossambicus & August 2013 & Rajapur & $22^{\circ} 33^{\prime} 42^{\prime \prime} \mathrm{N}$ & $88^{\circ} 49^{\prime} 51^{\prime \prime} \mathrm{E}$ & $\begin{array}{l}\text { growth } \\
\text { White gills, gill }\end{array}$ & 0 & retardation \\
\hline 10 & O. mossambicus & November 2013 & Belgachia & $22^{\circ} 36^{\prime} 34^{\prime \prime} \mathrm{N}$ & $88^{\circ} 23^{\prime} 17^{\prime \prime} \mathrm{E}$ & $\begin{array}{l}\text { necrosis } \\
\text { Cutaneous }\end{array}$ & 40 & $\begin{array}{l}\text { Gill rot } \\
\text { Bacillus }\end{array}$ \\
\hline 11 & $\begin{array}{l}\text { O. niloticus } \\
\text { O. niloticus }\end{array}$ & January 2014 & Haripota & $22^{\circ} 30^{\prime} 01^{\prime \prime} \mathrm{N}$ & $88^{\circ} 29^{\prime} 04^{\prime \prime} \mathrm{E}$ & haemorrhage & 0 & $\begin{array}{l}\text { infection } \\
\text { Streptococcal }\end{array}$ \\
\hline 12 & (monosex) & September 2014 & Pratapnagar & $22^{\circ} 27^{\prime} 32^{\prime \prime} \mathrm{N}$ & $88^{\circ} 28^{\prime} 57^{\prime \prime} \mathrm{E}$ & $\begin{array}{l}\text { A } \\
\text { Cutaneous }\end{array}$ & $55-70$ & infection* \\
\hline 13 & O. mossambicus & February 2015 & Garia & $22^{\circ} 27 ' 55^{\prime \prime} \mathrm{N}$ & $88^{\circ} 24^{\prime} 24^{\prime \prime} \mathrm{E}$ & haemorrhage & 0 & Pseudomoniasis \\
\hline 14 & O. mossambicus & February 2015 & Chakgaria & $22^{\circ} 28^{\prime} 49^{\prime \prime} \mathrm{N}$ & $88^{\circ} 24^{\prime} 00^{\prime \prime} \mathrm{E}$ & $\begin{array}{l}\text { White gills } \\
\text { Haemorrhagic }\end{array}$ & 2 & Gill rot \\
\hline$\underline{15}$ & O. mossambicus & March 2015 & Chakgaria & $22^{\circ} 28^{\prime} 45^{\prime \prime} \mathrm{N}$ & $88^{\circ} 24^{\prime} 00^{\prime \prime} \mathrm{E}$ & spots on body & $2-3$ & Aeromoniasis \\
\hline
\end{tabular}

A: Lethargy, poor escape response, erratic movement, curvature of spinal cord, excess mucous secretion on gills, haemorrhagic inner and outer operculum and focal cutaneous haemorrhages on belly, lower jaw and at the base of paired fins, abdominal ascites, organs discolouration and haemorrhagic

streaking on BHIA, and finally maintained on BHIA slants at room temperature $\left(28 \pm 2^{\circ} \mathrm{C}\right)$ and also as glycerol stock at $-20^{\circ} \mathrm{C}$ for further characterization.

\section{Phenotypic characterization of bacterial isolates of monosex Nile tilapia}

A series of biochemical tests were performed to identify the bacterial strains to the genus level (Collins et al. 2004, Austin and Austin 2012). Further, characterizations of the bacterial strains (TBT1, TKT1, TKT2, TKR1, TKR2, TIOT1, TIOT2, TOOT, TIOK, TKK, and TIOK) were done by an automated bacterial identification system (VITEK-2 Compact, bioMérieux, France). The hemolytic activity of Gram-positive and catalase negative diplococci strains - TBT1, TKT1, TKT2, TIOT1, and TOOT were tested on sheep blood agar (HiMedia, India, code no MP-1301) separately (Collins et al. 2004). These isolates were also characterized biochemically 
using Rapid HiStrep ${ }^{\mathrm{TM}}$ biochemical test kits specific for Streptococcus sp. (HiMedia, India).

\section{Molecular characterization of bacterial isolates of monosex Nile tilapia}

The genomic DNA of five Gram-positive and catalase negative diplococci strains (TBT1, TKT1, TKT2, TIOT1, and TOOT) were isolated using a Genomic DNA isolation kit (Macherey-Nagel, Germany) as per the manufacturer's protocol. The $16 \mathrm{~S}$ small subunit ribosomal RNA (16S rRNA) was amplified by Eppendorf Master Cycler Pro $S$ using a set of universal prokaryotic primers 8F, 5'-AGAGTTTGATCCTGGCTCAG-3', and 1492R, 5'-GGTTACCTTGTTACG ACTT-3' (Eden et al. 1991). The PCR master mix contained $50 \mathrm{ng}$ of genomic DNA, $10 \mu \mathrm{M}$ of each primer, and $2 \times$ PCR TaqMixture (HiMedia, India). Amplification was done by initial denaturation at $95^{\circ} \mathrm{C}$ for $5 \mathrm{~min}$, followed by 35 cycles of denaturation at $95^{\circ} \mathrm{C}$ for 30 sec, annealing of primers at $44^{\circ} \mathrm{C}$ for $30 \mathrm{sec}$, and extension at $72^{\circ} \mathrm{C}$ for $60 \mathrm{sec}$. The final extension was at $72^{\circ} \mathrm{C}$ for $5 \mathrm{~min}$. The PCR products were analyzed on a $1.5 \%$ agarose gel containing $0.5 \mu \mathrm{g} \mathrm{mL}^{-1}$ ethidium bromide in $1 \times$ Tris-acetate-EDTA (TAE) buffer.

\section{Sequencing and phylogenetic analyses}

The PCR amplicons were first purified using the EXO-SAP treatment to determine the concentration of purified DNA and then subjected to automated DNA sequencing on an ABI 3730xl Genetic Analyzer. Sequencing was carried out using a BigDye ${ }^{\circledR}$ Terminator v3.1 Cycle sequencing kit (Applied Biosystems, USA) following the manufacturers' instructions. Electrophoresis and data analysis were conducted on an ABI 3730xl Genetic Analyzer. The forward and reverse sequences were assembled by DNA Baser Sequence Assembler v3.5.3 (2012) to form consensus sequences. Phylogenetic analysis was performed on a selection of thirty $16 \mathrm{~S}$ rRNA gene sequences that comprised all the new consensus sequences, closely related sequences of the same genus determined by Basic Local Alignment Search Tool (BLAST) from the NCBI GenBank database (http://blast.ncbi.nlm.nih.gov), and other representatives of lactic acid bacteria and the families Micrococcaceae and Enterobacteriaceae. Sequence alignment was performed with the Multiple Sequence Comparison by Log-Expectation (MUSCLE) program (Edgar 2004), and the phylogenetic tree was constructed using MEGA6 software (Tamura et al. 2013). The evolutionary distance was evaluated by the neighbor-joining method using the Kimura 2-parameter model (Kimura 1980) with 1000 bootstrap replicates. The nucleotide sequences of five Gram-positive and catalase negative diplococci strains (TOOT, TKT2, TKT1, TBT1, and TIOT1) of the present study were deposited in the NCBI GenBank under accession numbers KP898206, KP898207, KP898208, KP898209, and KP898210, respectively.

\section{Histopathology}

Various organs of naturally infected monosex $O$. niloticus were fixed in Bouin's solution for $24 \mathrm{~h}$. The fixed organ, viz., brain, kidney, liver, spleen and intestine, samples were processed with standard techniques and embedded in paraffin wax. Thin $(5 \mu \mathrm{m})$ sections were prepared and stained with hematoxylin and eosin (Presnell and Schreibman 1997) for the detection of histopathological changes.

\section{Results}

\section{Gross and clinical signs of diseased monosex Nile tilapia}

The gross and clinical signs observed in diseased monosex Nile tilapia include lethargy, poor escape response, erratic movement, spinal cord curvature, excess mucous secretion on gills, hemorrhagic inner and outer opercula, and focal cutaneous hemorrhages on the belly, lower jaw, and at the base of paired fins. 
Table 2

Phenotypic characteristics of Enterobacteriaceae and the motile aeromonad group of bacteria isolated from the kidney of monosex Nile tilapia, Oreochromis niloticus, assessed with the VITEK-2 Compact system (bioMérieux, France)

\begin{tabular}{|c|c|c|c|c|c|}
\hline \multirow[b]{2}{*}{ Characteristics } & \multicolumn{3}{|c|}{ Enterobacteriaceae } & \multicolumn{2}{|c|}{ Motile aeromonads } \\
\hline & TKK & TIOK & TOOK & TKR1 & TKR2 \\
\hline $\begin{array}{l}\text { D-Glucose (dGLU) } \\
\text { (d) }\end{array}$ & + & + & + & + & + \\
\hline Saccharose/sucrose (SAC) & - & + & + & + & + \\
\hline D-Cellobiose (dCEL) & - & + & + & - & - \\
\hline Adonitol (ADO) & - & - & - & - & - \\
\hline L-Arabitol (IARL) & - & - & - & - & - \\
\hline D-Mannitol (dMAN) & + & + & + & + & + \\
\hline D-Sorbitol (dSOR) & + & + & + & - & - \\
\hline D-Maltose (dMAL) & + & + & + & + & + \\
\hline D-Mannose (dMNE) & + & + & + & + & + \\
\hline D-Tagatose (dTAG) & - & - & - & - & - \\
\hline D-Trehalose (dTRE) & + & + & + & + & + \\
\hline $\mathrm{H}_{2} \mathrm{~S}$ production $\left(\mathrm{H}_{2} \mathrm{~S}\right)$ & - & - & - & - & - \\
\hline Lysine decarboxylase (LDC) & + & + & - & - & - \\
\hline Orinithine decarboxylase (ODC) & + & - & + & - & - \\
\hline L-Malate assimilation (IMLTa) & + & - & - & + & + \\
\hline Citrate (sodium) (CIT) & - & + & + & + & - \\
\hline Urease (URE) & - & + & - & - & - \\
\hline Fermentation/glucose (OFF) & + & + & + & + & + \\
\hline Phosphatase (PHOS) & - & + & - & - & - \\
\hline Beta-glucoronidase (BGUR) & + & - & - & - & - \\
\hline Lipase (LIP) & - & - & - & - & + \\
\hline Alpha-glucosidase (AGLU) & - & - & - & - & - \\
\hline Beta-xylosidase (BXYL) & - & + & + & - & - \\
\hline Beta-galactosidase (BGAL) & + & + & + & + & + \\
\hline Ala-Phe-Pro-arylamidase (APPA) & - & - & - & + & + \\
\hline L Pyrrolydonyl-arylamidase (PyrA) & - & + & - & - & - \\
\hline Beta-N-Acetyl-glucosaminidase (BNAG) & - & - & + & + & + \\
\hline Glutamyl arylamidase pNA (AGLTp) & - & - & - & - & - \\
\hline Gamma-glutamyl transferase (GGT) & - & + & + & - & + \\
\hline Beta-alanine arylamidase pNA (BAlap) & - & - & - & - & - \\
\hline L-Proline arylamidase (ProA) & + & + & + & + & + \\
\hline Tyrosine arylamidase (TyrA) & + & + & + & + & + \\
\hline Beta-N-acetyl-galactosaminidase (NAGA) & - & - & + & - & + \\
\hline Glycine arylamidase (GlyA) & - & + & + & - & - \\
\hline Glu-Gly-Arg-arylamidase (GGAA) & - & - & - & + & + \\
\hline Ellman (ELLM) & $(-)$ & - & - & + & + \\
\hline L-Lactate assimilation (ILATa) & - & - & - & - & - \\
\hline L-Histidine assimilation (IHISa) & - & - & - & - & - \\
\hline 5-Keto D-gluconate (5KG) & - & + & - & - & - \\
\hline Palatinose (PLE) & - & + & + & - & - \\
\hline Malonate (MNT) & - & + & + & - & - \\
\hline L-Lactate alkalinisation (ILATk) & + & + & + & + & - \\
\hline Succinate alkalinisation (SUCT) & + & + & + & + & + \\
\hline Alpha-galactosidase (AGAL) & + & + & + & - & - \\
\hline Beta-glucosidase (BGLU) & - & + & - & - & - \\
\hline Coumarate (CMT) & + & - & - & + & + \\
\hline O/129 Resistance (0129R) & + & + & + & + & + \\
\hline
\end{tabular}

TIOK: Klebsiella pneumoniae ssp. pneumoniae, TKK: Escherichia coli, TOOK: Enterobacter cloacae complex, TKR1: Aeromonas sobria and TKR2: Aeromonas caviae 
Internally, abdominal ascites, kidney hemorrhages, and organ discoloration were observed (Table 1).

\section{Phenotypic characterization of bacterial strains from monosex Nile tilapia}

Inocula from brain and hemorrhagic operculum samples yielded predominantly round, white, glossy, semi-convex colonies on BHIA plates within $48 \mathrm{~h}$, and no growth was observed on other media. Inocula from kidney samples yielded cream to white and yellow and green colors with black centered colonies on BHIA, GSPA, and RSA, respectively. The absence of pink colored colonies on GSPA ruled out the involvement of Pseudomonas spp. in this diseased condition. The five bacterial strains isolated from kidney on GSPA and RSA were Gram-negative, motile, glucose fermenting rods. Two of the isolates were oxidase positive and were presumptively identified as Aeromonas sobria (TKR1) and A. caviae (TKR2). The remaining three oxidase negative isolates were presumptively identified as Klebsiella pneumoniae ssp. pneumoniae (TIOK), Escherichia coli (TKK), and Enterobacter cloacae complex (TOOK) by VITEK-2 compact (bioMérieux, France) with 97\%, 98\%, and $98 \%$ probability, respectively (Table 2). The Gram-positive coccus in clusters and oxidase negative and catalase positive isolate from the hemorrhagic operculum on BHIA was presumptively identified as Staphylococcus epidermis (TIOT2) with 97\% probability by the Vitek 2 Compact system.

The bacterial strains isolated from the brain, operculum, and kidney on BHIA $(n=5)$ were Gram-positive, diplococci, and oxidase and catalase negative. Biochemical characterizations of these isolates as assessed by Rapid HiStrep ${ }^{\mathrm{TM}}$ biochemical test kits are given in Table 3. The Rapid HiStrep ${ }^{\mathrm{TM}}$ kit identified these strains (TKT1, TKT2, TBT1, TOOT, and TIOT1) as $S$. agalactiae presumptively. The results of additional biochemical tests of five presumptive $S$. agalactiae strains by the VITEK-2 compact are presented in Table 3. All presumptive $S$. agalactiae strains were non-hemolytic.

\section{Molecular characterization of bacterial strains from monosex Nile tilapia}

The identification of five presumptive $S$. agalactiae strains were further confirmed by PCR and phylogenetic analysis. The universal prokaryotic primers $8 \mathrm{~F}$ and $1492 \mathrm{R}$ successfully amplified $\approx 1450$ bp sequence of the $16 \mathrm{~S}$ rRNA gene of these strains. On the basis of gene sequence similarity, the strains were identified as $S$. agalactiae that showed $98-99 \%$ homogeneity with other such species. Our S. agalactiae strains exhibited $86-91 \%$ similarity with other lactic acid bacteria; while the non-lactic acid bacteria showed only $78-81 \%$ similarity. Phylogenetic analysis of $S$. agalactiae strains of the present study and from the NCBI GenBank database formed a monophyletic group with high nodal support (Fig. 1). Other Streptococcus spp. also clustered together forming a separate clade. The $S$. agalactiae strain TOOT clustered along with other strains that were isolated from tilapia (Oreochromis spp.), and they branched out separately with $88 \%$ node support. The rest of the strains formed a separate clade

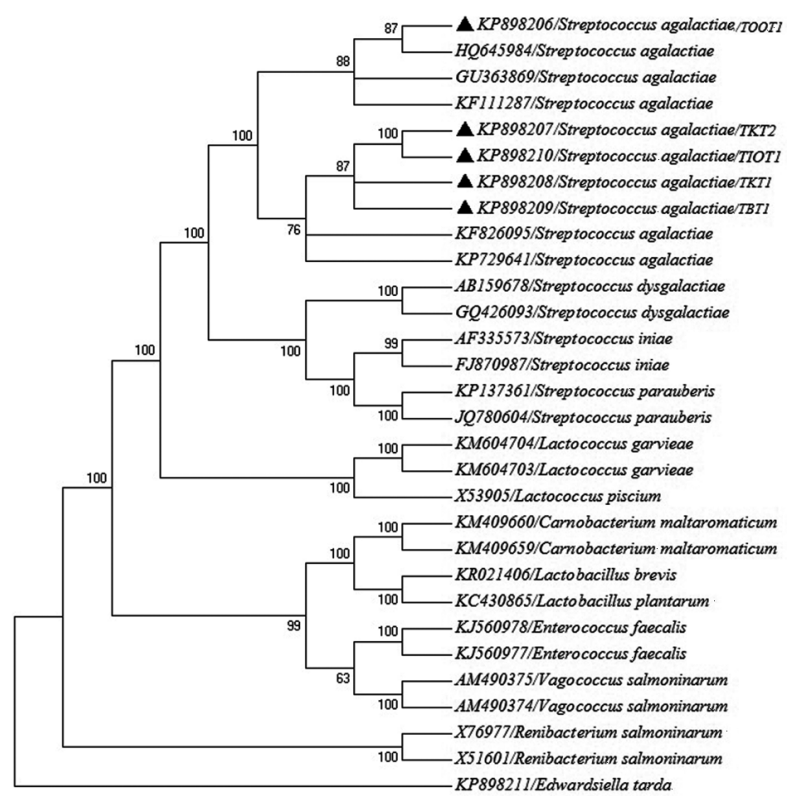

Figure 1. Phylogenetic tree of Streptococcus agalactiae strains isolated from the brain, kidney, and opercular hemorrhagic areas of diseased monosex Nile tilapia, Oreochromis niloticus, generated by the neighbor-joining method with 1000 bootstrap replicates. GenBank accession numbers are provided for each species. 
Table 3

Phenotypic characteristics of Streptococcus agalactiae and Staphylococcus epidermis strains isolated from different organs of monosex Nile tilapia, Oreochromis niloticus, assessed with HiStrep ${ }^{\mathrm{TM}}$ (HiMedia, India) and the VITEK-2 Compact system (bioMérieux, France)

\begin{tabular}{|c|c|c|c|c|c|c|}
\hline \multirow[b]{2}{*}{ Biochemical characteristics } & \multicolumn{5}{|c|}{ S. agalactiae strains and reaction* } & \multirow{2}{*}{$\begin{array}{l}\text { SE** } \\
\text { TIOT2 }\end{array}$} \\
\hline & TBT1 & TKT1 & TKT2 & TIOT1 & TOOT & \\
\hline Gram reaction & + & + & + & + & + & + \\
\hline Morphology & $\mathrm{DC}$ & DC & DC & $\mathrm{DC}$ & $\mathrm{DC}$ & $\mathrm{C}$ \\
\hline Catalase & - & - & - & - & - & + \\
\hline Oxidase & - & - & - & - & - & - \\
\hline Haemolysis & $\gamma$ & $\gamma$ & $\gamma$ & $\gamma$ & $\gamma$ & ND \\
\hline \multicolumn{7}{|l|}{ HiStrepTM } \\
\hline Voges Proskaur reaction & + & + & + & + & + & ND \\
\hline Esculin hydrolysis & - & - & - & - & - & ND \\
\hline L-pyrrolidonyl arylamidase (PYR) & - & - & - & - & - & ND \\
\hline Ortho-nirophenyl $\beta$ - D- galactopyranoside & - & - & - & - & - & ND \\
\hline Arginine utilization & + & + & + & + & + & ND \\
\hline Glucose & + & + & + & + & + & ND \\
\hline Lactose & - & - & - & - & - & ND \\
\hline Arabinose & - & - & - & - & - & ND \\
\hline Sucrose & + & + & + & + & + & ND \\
\hline Sorbitol & - & - & - & - & - & ND \\
\hline Mannitol & - & - & - & - & - & ND \\
\hline Raffinose & - & - & - & - & - & ND \\
\hline \multicolumn{7}{|l|}{ VITEK-2 compact system $* * *$} \\
\hline D-Amygdalin (AMY) & - & - & - & - & - & - \\
\hline Phosphatidyl inositol phospholipase C (PIPLC) & - & - & - & - & - & - \\
\hline D-Xylose (dXYL) & - & - & - & - & - & - \\
\hline Arginine dihydrolase1 (ADH1) & + & + & + & + & + & + \\
\hline Beta-galactosidase (BGAL) & - & - & - & - & - & - \\
\hline Alpha-glucosidase (AGLU) & - & - & - & - & $(-)$ & - \\
\hline Ala-Phe-Pro arylamidase (APPA) & - & - & - & - & - & - \\
\hline Cyclodextrin (CDEX) & - & - & - & - & - & - \\
\hline L-Aspartate arylamidase (AsPA) & - & - & - & - & - & - \\
\hline Beta-galactopyranosidase (BGAR) & - & - & - & - & - & - \\
\hline Alpha-mannosidase (AMAN) & - & - & - & - & - & - \\
\hline Phosphatase (PHOS) & - & - & - & - & - & - \\
\hline Leucine arylamidase (LeuA) & - & - & - & - & - & - \\
\hline D-Sorbitol (dSOR) & - & - & - & - & - & - \\
\hline Urease (URE) & - & - & - & - & - & + \\
\hline Polymixin B resistance (POLYB) & + & + & + & + & + & - \\
\hline D-Galactose (dGAL) & - & + & + & - & + & + \\
\hline D-Ribose (dRIB) & + & + & + & + & + & - \\
\hline L-Lactate alkalinization (ILATk) & - & - & - & - & - & - \\
\hline Lactose (LAC) & - & - & - & - & - & + \\
\hline N-Acetyl-D-glucosamine (NAG) & + & + & + & + & + & - \\
\hline D-Maltose (dMAL) & + & + & + & + & + & + \\
\hline Bacitracin resistance (BACI) & - & - & - & - & + & - \\
\hline Novobiocin resistance (NOVO) & - & - & - & - & + & - \\
\hline Growth in $6.4 \% \mathrm{NaCl}$ (NC6.5) & - & - & - & - & - & + \\
\hline D-Mannitol (dMAN) & - & - & - & - & - & - \\
\hline D-Mannose (dMNE) & + & + & + & + & + & + \\
\hline Methyl-B-D-glucopyranoside (MBdG) & - & - & - & - & - & - \\
\hline Pullulan (PUL) & - & - & - & - & - & - \\
\hline
\end{tabular}


Cont. Table 3

\begin{tabular}{lllllll}
\hline \hline & \multicolumn{3}{l}{ S. agalactiae strains and reaction* } & & \multicolumn{2}{c}{ SE* $^{*}$} \\
\cline { 2 - 6 } Biochemical characteristics & TBT1 & TKT1 & TKT2 & TIOT1 & TOOT & TIOT2 \\
\hline D-Raffinose (dRAF) & + & + & + & - & - & - \\
O/129 Resistance (comp. vibrio) (O129R) & - & - & - & - & - & + \\
Salicin (SAL) & $(-)$ & + & + & + & + & - \\
Sucrose (SAC) & + & + & + & + & + & + \\
D-Trehalose (dTRE) & + & + & + & + & + & - \\
Arginine dihydrolase 2(ADH2s) & - & - & - & - & + & + \\
Optochin resistance (OPTO) & + & + & + & + & + \\
\hline \hline
\end{tabular}

* Biochemical characteristics of the bacterial strains from other cases of streptococcal infection (Table 1) were similar

** Staphylococcus epidermis

***Identified as Pediococcus pentosaceus by VITEK-2 compact system as the software database did not have the details of non-clinical S. agalactiae

with strains isolated from marine fish Trachinotus ovatus (L.) and had 76\% node support.

\section{Histopathology of $S$. agalactiae infection in naturally infected monosex Nile tilapia}

Histopathologically, the brain of naturally infected tilapia was found to have signs of meningoencephalitis. It was visible by the presence of hemorrhages, edema, inflamed neurons with margination, hypertrophied nuclei, marginated hemocytes, and hypertrophied hemocytes (Fig. 2a-f). Meningoencephalitis (Fig. 2c) and granuloma-like structures (Fig. 2d) were observed in the brain tissue. The kidney of infected tilapia exhibited extensively necrotized tissue, glomerulopathy with dilated Bowman's capsules, and constricted tubular lumen with vacuolation in the epithelial layer (Fig. 3a-d). The hematopoietic tissue of the kidney was hemorrhagic and hypoplastic in appearance (Fig. 3a). At higher magnification, cellular and nuclear hypertrophy, melanin reaction, and eosinophilic ground substances were visible (Fig. 3b). The liver of naturally infected tilapia showed massive necrosis of hepatocytes as most of them appeared edema $(\mathrm{O})$. without a nucleus (Fig. 4a) and with marked fatty changes and hemorrhagic areas (Fig. 4b). There was karyolysis in hepatocytes as well as marginated hepatocytes with nuclear hypertrophy (Fig. 4a), pyknotic nuclei, hypertrophied nuclei, and eosinophilic deposition (Fig. 4b). Congestion of liver blood capillaries, necrosis of hepatocytes, melanin reaction, eosinophilic ground substances (Fig. 4c), hemosiderin
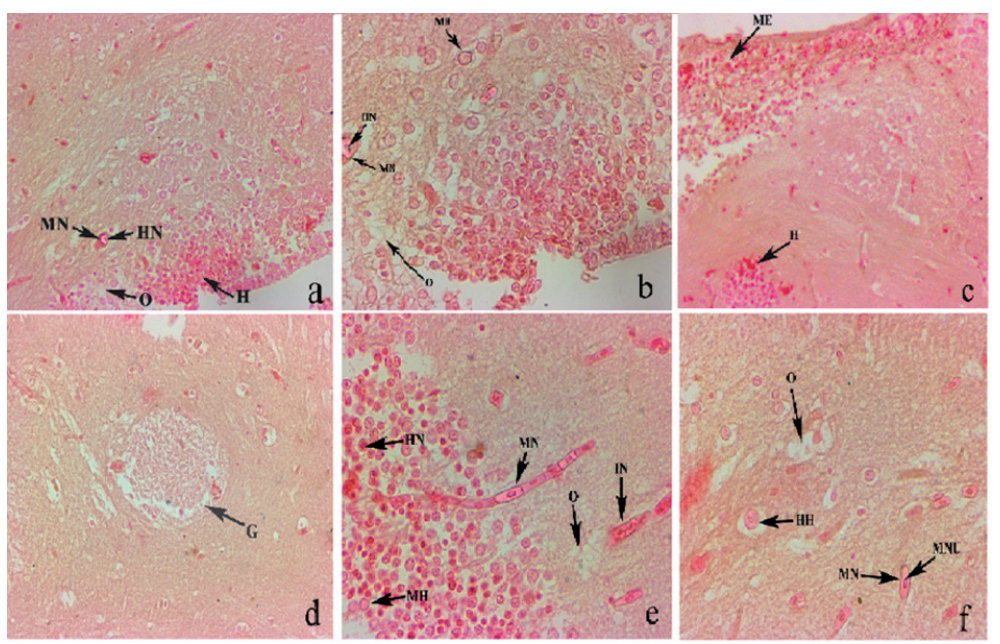

Figure 2. Histopathological changes in the brain of monosex Nile tilapia, Oreochromis niloticus, with Streptococcus agalactiae infection showing [a]: hemorrhages $(\mathrm{H})$, increased intercellular space indicating edema $(\mathrm{O})$, inflamed neurons with margination (MN), and hypertrophied nuclei $(\mathrm{HN})$; [b]: inflamed neurons with margination $(\mathrm{MN})$, hypertrophied nuclei $(\mathrm{HN})$, marginated hemocytes $(\mathrm{MH})$, and increased intercellular space indicating edema $(\mathrm{O})$; [c]: meningoencephalitis (ME) and hemorrhages $(\mathrm{H})$; [d]: granuloma-like structure $(\mathrm{G})$; [e]: marginated hemocytes $(\mathrm{MH})$, marginated neurons (MN), hypertrophied nuclei $(\mathrm{HN})$, inflamed neurons (IN), and increased intercellular space indicating edema (O); [f]: marginated neurons $(\mathrm{MN})$ with marginated nuclei $(\mathrm{MNU})$, hypertrophied hemocytes $(\mathrm{HH})$, and 


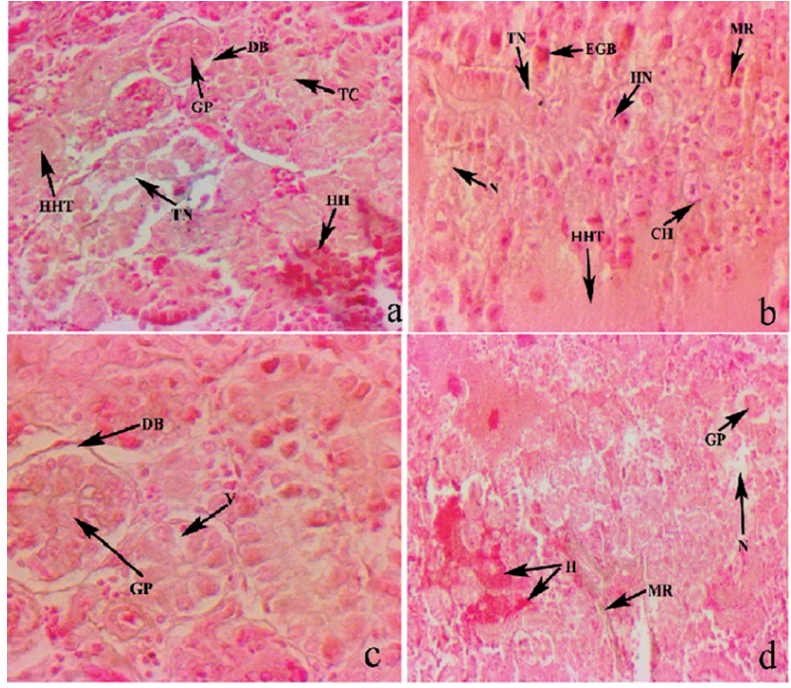

Figure 3. Histopathological changes in the kidney of monosex Nile tilapia, Oreochromis niloticus, with Streptococcus agalactiae and other bacterial infection showing [a]: tubular necrosis (TN), hemorrhagic hematopoietic tissue (HH), glomerulopathy (GP) with dilated Bowman's capsule (DB), constricted tubular lumen (TC), and hypoplastic hematopoietic tissue (HHT); [b]: cellular and nuclear hypertrophy (CH and $\mathrm{HN})$, tubular necrosis (TN), extensive necrotized kidney (N), melanin reaction (MR), hypoplastic haematopoietic tissue (HHT), and eosinophilic ground substances (EGS); [c]: glomerulopathy (GP) with dilated Bowman's capsule (DB), vacuolation of nephritic tubular epithelium (V); [d]: extensive necrotized kidney $(\mathrm{N})$, hemorrhagic area $(\mathrm{H})$, melanin reaction (MR), and glomerulopathy (GP).

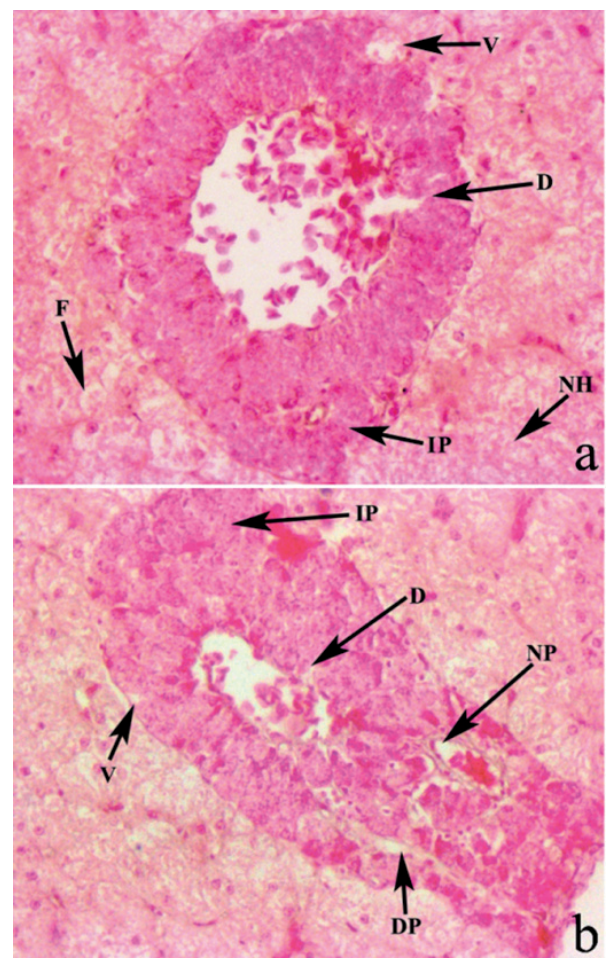

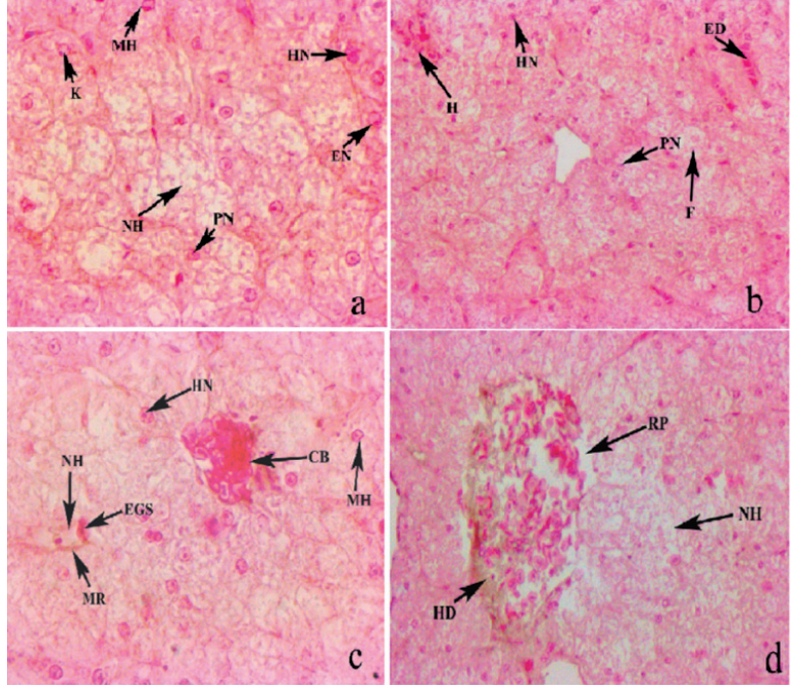

Figure 4. Histopathological changes in the liver of monosex Nile tilapia, Oreochromis niloticus, with Streptococcus agalactiae and other bacterial infection showing [a]: massive necrosis of hepatocytes $(\mathrm{NH})$ as most of them appeared without nuclei, hepatocytes with pyknotic nuclei (PN) and eccentric nuclei (EN), karyolysis in hepatocytes (K), marginated hepatocytes $(\mathrm{MH})$ with nuclear hypertrophy $(\mathrm{HN})$; [b]: marked fatty changes $(\mathrm{F})$, pyknotic nuclei (PN) and hypertrophied nuclei (HN), eosinophilic deposition (ED), and hemorrhagic areas $(\mathrm{H})$; [c]: congestion of liver blood capillaries $(\mathrm{CB})$, necrosis of hepatocytes $(\mathrm{NH})$, melanin reaction (MR) indicating inflammatory response, eosinophilic ground substances (EGS), marginated hepatocytes $(\mathrm{MH})$, and nuclear hypertrophy $(\mathrm{HN})$; [d]: necrosis of hepatocytes $(\mathrm{NH})$, hemosiderin deposition (HD), and ruptured portal vain (RP).

deposition, and a ruptured portal vein were also noted (Fig. 4d). Changes were also found in pancreatic tissue, which included degradation and vacuolation of exocrine pancreatic cells, inflammation and necrosis of pancreatic cells, fatty changes and necrosis of hepatocytes, and dilation of the pancreatic duct (Fig. 5a-b). The spleen of infected tilapia showed melanomacrophage aggregates, extensive necrosis, congestion, hemocyte infiltration, hemosiderin deposition, cellular hypertrophy, vasodilation, darkly stained nuclei, and eosinophilic ground substances (Fig. 6a-d). Granuloma-like lesions, similar to those

Figure 5. Histopathological changes in the pancreas of monosex Nile tilapia, Oreochromis niloticus, with Streptococcus agalactiae and other bacterial infection showing [a]: degradation (D) and vacuolation (V) of exocrine pancreatic cells, inflammation of pancreatic cells (IP), fatty changes in hepatocytes (F), and necrosis of hepatocytes (NH); [b]: degradation (D) and vacuolation (V) of exocrine pancreatic cells, inflammation of pancreatic cells (IP), necrosis of pancreatic cells (NP), dilation of pancreatic duct (DP). 


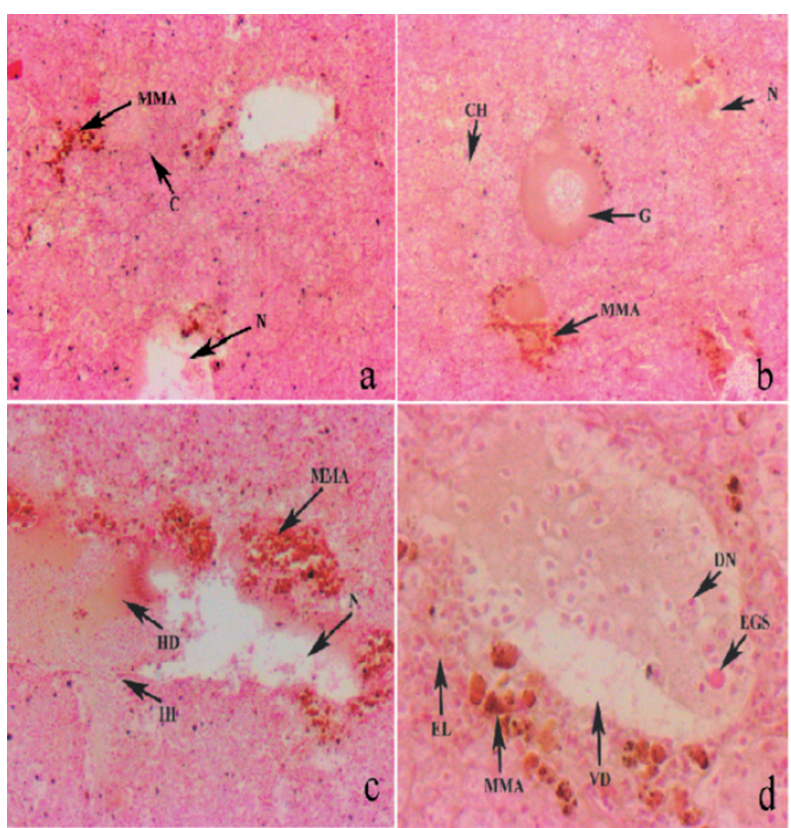

Figure 6. Histopathological changes in the spleen of monosex Nile tilapia, Oreochromis niloticus, with Streptococcus agalactiae and other bacterial infection showing [a]: melanomacrophage aggregates (MMA), extensive necrosis $(\mathrm{N})$, and congestion $(\mathrm{C})$; [b]: granuloma-like lesions (G), melanomacrophage aggregates (MMA), cellular hypertrophy $(\mathrm{CH})$, and necrosis $(\mathrm{N})$; [c]: melanomacrophage aggregates (MMA), extensive necrosis (N), hemocyte infiltration (HI), and hemosiderin deposition (HD); [d]: vasodilation (VD) with emigration of leukocytes (EL) to the site of infection, melanomacrophage aggregates (MMA) surrounding blood capillaries, hemocytes with darkly stained nuclei (DN), and eosinophilic ground substances (EGS).

found in the brain, were also observed in the spleen (Fig. 6b). The blood capillaries of the spleen were dilated, and leukocytes were emerging to the site of infection (Fig. 6d). The bacterial infection also affected the intestine of tilapia and caused degradation of columnar epithelium exposing the enterocytes of the villi and microvilli, inflammation at the tip of the microvilli, a hemorrhagic area at the villi, and disruption and inflammation in the tunica muscularis and submucosa (Fig. 7a-c). Karyolysis, pyknotic nuclei, vacuolation, marginated cells, and inclusion-like bodies were also found in the intestine (Fig. 7c).

\section{Discussion}

The present study identified in S. agalactiae infection in the brain and mixed bacterial infection in the

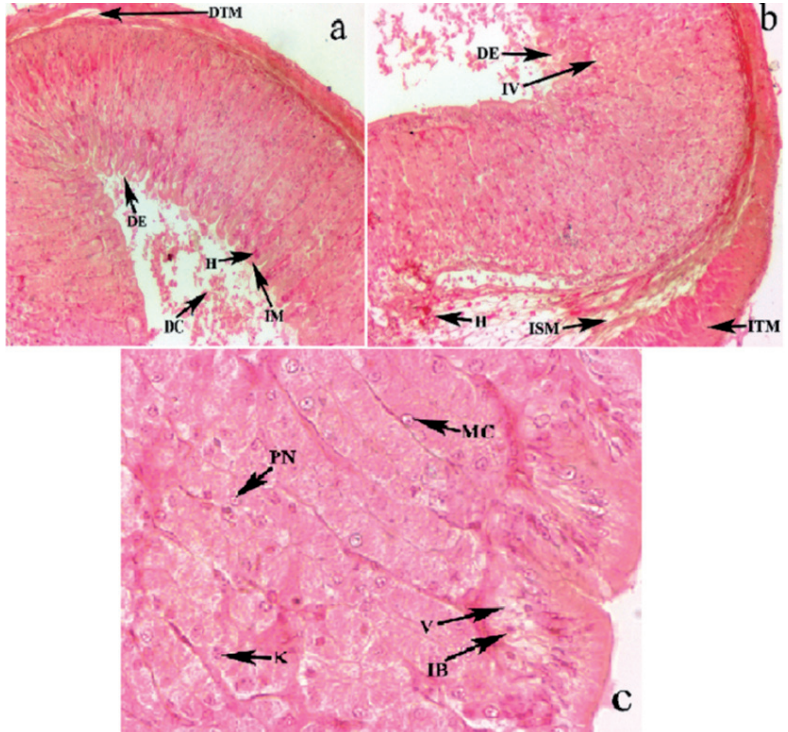

Figure 7. Histopathological changes in the intestine of monosex Nile, tilapia Oreochromis niloticus, with Streptococcus agalactiae and other bacterial infection showing [a]: degradation of columnar epithelium (DE) exposing the enterocytes of the villi and microvilli, inflammation at the tip of the microvilli (IM), hemorrhagic area at the villi $(\mathrm{H})$, disruption in tunica muscularis (DTM), and degraded cells in the gut lumen (DC); [b]: degradation of columnar epithelium (DE) exposing the enterocytes of the villi and microvilli, inflammation of villi (IV), inflammation of tunica muscularis (ITM), inflammation of submucosa (ISM), and hemorrhages $(\mathrm{H})$; [c]: karyolysis (K), pyknotic nuclei (PN), vacuolation $(\mathrm{V})$, marginated cells (MC) with pycnotic nuclei, and inclusion like bodies (IB).

kidney of monosex $O$. niloticus. The occurrence of streptococcal infection in fish, especially meningoencephalitis in tilapia, was uncommon in India until this observation. In an earlier study, infections caused by Lactococcus garvieae are reported in rainbow trout farms in India by Shahi et al. (2014). Infection from Streptococcus spp. that causes acute mortality from systemic infection has been reported widely in many fish species such as Oreochromis sp. (Abuseliane et al. 2011, Alsaid et al. 2013), O. niloticus ( $\mathrm{Li}$ et al. 2013, Wang et al. 2013), Epinephelus lanceolatus (Bloch) (Bowater et al. 2012), Sparus auratus L. (Evans et al. 2002), Pampus argenteus (Euphrasen) (Duremdez et al. 2004), and Schizothorax prenanti (Tchang) (Geng et al. 2012). The bacterium $S$. iniae is considered to be the primary pathogen that causes highly frequent streptococcal infection in tilapia (Deng et al. 2010). 
However, in recent years, the problems of $S$. agalactiae infection in tilapia culture has gradually become apparent. Severe streptococcal infection in tilapia caused by S. agalactiae has occurred in China, causing heavy losses (Zhang et al. 2008).

The five diplococci strains, presumptively identified as S. agalactiae with the Rapid HiStrep ${ }^{\mathrm{TM}}$ biochemical test kit, were characterized as Pediococcus pentosaceus by the VITEK-2 Compact system as the software database did not include details regarding non-clinical $S$. agalactiae. Since this identification contradicted molecular identification, the VITEK-2 data were used only to characterize the bacterial isolates phenotypically. The five strains of S. agalactiae from diseased tilapia were non-hemolytic, which corroborates the observations of Wang et al. (2013) recorded in $S$. agalactiae isolates of Nile tilapia in China. $\beta$-haemolytic $S$. agalactiae strains responsible for mass mortality in farmed red tilapia (Oreochromis sp.) were also reported (Abuseliane et al. 2011). Newly introduced fish, the movement of infected fish among farms, infected fish feces (Nguyen et al. 2002), and using trash fish as feed (Kim et al. 2007) are believed to be responsible for outbreaks of $S$. agalactiae infection. Evans et al. (2006b) and Amal et al. (2011) conclude that high stocking density, poor water quality, water temperature $>31^{\circ} \mathrm{C}$, and intensive aquaculture predispose tilapia to outbreaks of $S$. agalactiae infection.

Phylogenetic analysis based on 16S rRNA gene sequences indicated that the five novel sequences belonged to the family Streptococcaceae, phylum Firmicutes, and fell within the evolutionary radiation of the genus Streptococcus. The 16S rRNA gene sequences of these bacteria were closely related to $S$. agalactiae. The gene sequence of $S$. agalactiae strain TOOT (accession number KP898206) had 98\% similarity to $S$. agalactiae strains isolated from tilapia with accession numbers HQ645984 (unpublished), GU363869 (Jing-Lin et al. 2010), and KF111287 (Li et al. 2013). However, other strains, viz., TKT1 (accession number KP898207), TKT2 (accession number KP898208), TBT1 (accession number KP898209), TIOT1 (accession number KP898210), exhibited 98\% similarity with S. agalactiae strains (accession numbers KF826095 and KP729641 (unpublished)) isolated from the marine fish T. ovatus. Minor variations in biochemical characteristics such as alanine arylamidase (AlaA), urease (URE), D-galactose (dGAL), D-raffinose (dRAF), salicin (SAL), and arginine dihydrolase 2 (ADH2s) were observed among the S. agalactiae strains (Table 3), which means that there were also variations in the phylogenetic analysis based on the infected host species. This suggested the possible existence of different genotypes of S. agalactiae in West Bengal, India.

Earlier reports on histopathological analysis revealed that $S$. agalactiae causes systemic infection in fish. The common histopathological lesions of $S$. agalactiae infection consisted of (i) focal to multifocal, mild to severe granulomatous inflammation and (ii) multifocal, acute, necrotic inflammatory lesions. Also, S. agalactiae has a predilection for the brain, which is the primary organ for infection (Hernandez et al. 2009, Bowater et al. 2012). Histological sections of infected tilapia brain revealed meningoencephalitis with hemorrhages, edema, inflamed neurons, and hypertrophied nuclei, all of which are indicators of $S$. agalactiae infection (Zamri-Saad et al. 2010, Alsaid et al. 2013). Sections of other major organs like liver, spleen, kidney, and intestine showed a variety of pathological conditions that included congestion, hemorrhagic and hyperplastic cells, necrosis, vacuolation, hemosiderin deposition, hypertrophic nuclei, melanomacrophage aggregation, and ruptured veins. The gastrointestinal (GI) tract is considered to be the main route of entry of $S$. agalactiae in tilapia, and the bacterium can replicate in the lumen of the GI tract (Comas 2005). According to Comas (2005), the replication process in the GI tract could be a pathogenic mechanism that might permit the permanent colonization of the mucosal epithelium. The intestinal histopathological findings on the degradation of the columnar epithelium in the present study provide supportive evidence for Comas's (2005) observations. Findings similar to the current observations were reported earlier in red tilapia, Oreochromis sp. (Zamri-Saad et al. 2010), in O. niloticus naturally infected with S. agalactiae (Li et al. 2013), and in red 
hybrid tilapia (Oreochromis sp.) experimentally infected with S. agalactiae (Alsaid et al. 2013). Additionally, histologic sections of the brain and spleen revealed the presence of granulomatous lesions. These observations are in agreement with earlier reports (Suanyuk et al. 2008, Li et al. 2013) that demonstrated that $S$. agalactiae infection caused granulomatous lesions.

The identification of $A$. sobria (TKR1) and $A$. caviae (TKR2) from the kidney of stressed fish, although presumptive as per Austin and Austin (2012), suggested the involvement of multiple pathogenic bacteria in eliciting the nephropathies of cultured monosex $O$. niloticus. Staphylococcus epidermis and all other Gram-negative bacteria isolated from opercular hemorrhages and the kidney of diseased tilapia, respectively, (Tables 2 and 3) were considered to be opportunistic pathogens as there are no reports of meningoencephalitis caused by these bacteria. The findings on mixed bacterial infection in the kidney of tilapia concur with Najiah et al. (2012), who isolated S. agalactiae along with Staphylococcus aureus and Buckholderia cepacia from infected cage-cultured red hybrid tilapia.

\section{Conclusion}

Current Indian government regulations do not permit commercial seed production of monosex Nile tilapia. Nevertheless, this report confirms the first identification of $S$. agalactiae from cultured monosex O. niloticus, which entered clandestinely across the border into West Bengal, India. This warrants stringent biosecurity and quarantine measures to prevent the spread of this emerging disease in tilapia and other culture species that share common aquatic environments. Further research is needed for continuous surveillance and development of disease management strategies to prevent outbreaks of $S$. agalactiae infection. Utilizing specific pathogen-free stock, quarantining new arrival fish stock, reducing overcrowding, avoiding overfeeding, maintaining separate water supplies for culture systems, minimizing unnecessary handling and transportation, frequently removing dying and dead fish, feeding pathogen-free rations, and maintaining excellent sanitary conditions (Klesius et al. 2008) will reduce the risks of $S$. agalactiae infection.

Acknowledgments. The research work was supported by the Indian Council of Agricultural Research, Government of India, New Delhi under the Niche Area of Excellence program. The authors thank the Vice-Chancellor, West Bengal University of Animal and Fishery Sciences, Kolkata for providing the necessary facilities for conducting the work.

Author contributions. T.J.A. contributed substantially to the study concept and design and drafted the article or revised it critically. H.A. was involved in the collection of diseased fish samples and the isolation, maintenance, and phenotypic characterization of bacterial isolates. The molecular characterization of the bacterial isolates was done by A.P., while S.B. contributed made substantial contributions to histological work and to interpretations of histopathology.

\section{References}

Abuseliana A.F., Daud H.H.M., Aziz S.A., Bejo S.K., Alsaid M. 2011 - Pathogenicity of Streptococcus agalactiae isolated from a fish farm in Selangor to juvenile red tilapia (Oreochromis sp.) - J. Anim. Vet. Adv. 10: 914-919.

Alsaid M., Daud H.H.M., Mustapha N.M., Bejo S.K., Abdelhadi Y.M., Abuseliane A.F., Hamdan R.H. 2013 Pathological findings of experimental Streptococcus agalactiae infection in red hyprid tilapia (Oreochromis sp.) - International Conference on Chemical, Agricultural and Medical Sciences (CAMS-2013), Kuala Lumpur, Malaysia: 70-73.

Amal M.N.A., Zamri-Saad M. 2011 - Streptococcosis in tilapia (Oreochromis niloticus): a review - Pertanika J. Trop. Agric. Sci. 34: 195-206.

Austin B., Austin D.A. 2012 - Bacterial fish pathogens: disease of farmed and wild fish, $5^{\text {th }}$ edition - Springer-Praxis Publication Ltd, Chichester, UK, 457 p.

Bowater R.O., Forbes-Faulkner J., Anderson I.G., Condon K., Robinson B., Kong F., Gilbert G.L., Reynolds A., Hyland S., Mcpherson G., Brien J.O., Blyde D. 2012 - Natural outbreak of Streptococcus agalactiae (GBS) infection in wild giant Queensland grouper, Epinephelus lanceolatus 
(Bloch), and other wild fish in northern Queensland, Australia - J. Fish Dis. 35: 173-186.

Chen M., Li L.P., Wang R., Liang W.W., Huan Y., Li J., Lei A.Y., Huang W.Y., Gan X. 2012 - PCR detection and PFGE genotype analyses of streptococcal clinical isolates from tilapia in China - Vet. Microbiol. 159: 526-530.

Collins C.H., Lyne P.M., Grange J.M., Falkinham III J.O. 2004 - Microbiological methods. $8^{\text {th }}$ edition - Arnold, London, UK, 456 p.

Comas J. 2005 - Replication of Streptococcosis in Red Tilapia and Implementation of Immunoperoxidase as a Diagnostic Technique of Disease in Colombia - Tesis de pregrado, Facultad de Medicina Veterinaria, Universidad Nacional de Colombia (in Spanish).

Deng X.W., Xie Z.X., Xie Z., Liu J.B., Pang Y.S., Xie L.J. 2010 - Isolation and identification of Streptococcus iniae in tilapia from Guangxi - Guangxi Agri. Sci. 41: 495-498 (in Chinese).

Duremdez R., Al-Marzouk A., Qasem J.A., Al-Harbi A., Gharabally H. 2004 - Isolation of Streptococcus agalactiae from cultured silver pomfret, Pampus argenteus (Euphrasen) in Kuwait - J. Fish Dis. 27: 307-310.

Eden P.A., Schmidt T.M., Blakemore R.P., Pace N.R. 1991 Phylogenetic analysis of Aquaspirillum magnetotacticum using polymerase chain reaction-amplified $16 \mathrm{~S}$ rRNA-specific DNA - Int. J. Syst. Bacteriol. 41: 324-325.

Edgar R.C. 2004 - MUSCLE: multiple sequence alignment with high accuracy and high throughput - Nucleic Acids Res. 32: 1792-1797.

Evans J.J., Klesius P.H., Glibert P.M., Shoemaker C.A., Al-Sarawi M.A., Landsberg J., Duremdez R., Al-Marzouk A., Al-Zenki S. 2002 - Characterization of beta-hemolytic Group B Streptococcus agalactiae in cultured gilthead seabream, Sparus auratus (L.) and wild mullet, Liza klunzingeri (Day), in Kuwait - J. Fish Dis. 5: 505-513.

Evans J.J., Klesius P.H., Shoemaker C.A. 2006a - An overview of streptococcus in warm-water fish - Aquacult. Health Int. 7: 10-14.

Evans J.J., Pasnik D.J., Klesius P.H. Shoemaker C.A. 2006b Identification and epidemiology of Streptococcus iniae and Streptococcus agalactiae in tilapia, Oreochromis spp. - International Symposium on Tilapia in Aquaculture, American Tilapia Association, Charles Town, WV, USA: 25-42.

Evans J.J., Bohnsack J.F., Klesius P.H., Whiting A.A., Garcia J.C., Shoemaker C.A., Takahashi S. 2008 - Phylogenetic relationships among Streptococcus agalactiae isolated from piscine, dolphin, bovine and human sources: a dolphin and piscine lineage associated with a fish epidemic in Kuwait is also associated with human neonatal infections in Japan - J. Med. Microbiol. 57: 1369-1376.

Fitzsimmons K., Martinez-Garcia R., Gonzalez-Alanis P. 2011 - Why tilapia is becoming the most important food fish on the planet - In: Proceedings of the 9th International Symposium on Tilapia in Aquaculture (Eds) L.P. Liu, K. Fitzsimmons, Shanghai: 9-18.

Geng Y., Wang K., Huang X.L., Chen D.F., Li C.W., Ren S.Y., Liao Y.T., Zhou Z.Y., Liu Q.F., Du Z.J., Lai W.M. 2012 Streptococcus agalactiae, an emerging pathogen for cultured Ya-fish, Schizothorax prenanti, in China Transbound. Emerg. Dis. 59: 369-375.

Hernandez E., Figueroa J., Iregui C. 2009 - Streptococcosis on a red tilapia, Oreochromis sp., farm: a case study - J. Fish Dis. 32: 247-252.

HiMedia 2009 - The HiMedia Manual. A Manual of Microbiology Laboratory Practice - HiMedia Laboratories Pvt. Ltd., Mumbai, India, 524 p.

Jing-Lin Z., Hong Y., Zhi-Ying Z., Da-Yu L., Wei X. 2010 Isolation, identification and drug sensitivity test of pathogenic Streptococcus from tilapias Oreochromis niloticus cultured in Hainan - Oceanol. Limnol. Sin. 41: 590-596.

Kim J.H., Gomez D.K., Choresca C.H., Park S.C. 2007 Detection of major bacterial and viral pathogens in trash fish used to feed cultured flounder in Korea Aquaculture 272: 105-110.

Kimura M.A. 1980 - A simple method for estimating evolutionary rate of base substitutions through comparative studies of nucleotide sequences - J. Mol. Evol. 16: 111-120.

Klesius P.H., Shoemaker C.A., Evans J.J. 2008 - Streptococcus: a worldwide fish health problem - In: 8th International Symposium on Tilapia in Aquaculture (Eds) H. Elghobashy, K. Fitzsimmons, A.S. Diab, Cairo, Egypt, 83-107.

Li Y.W., Liu L., Huang P.R., Fang W., Luo Z.P., Peng H.L., Wang X.Y., Li A.X. 2014 - Chronic streptococcosis in Nile tilapia, Oreochromis niloticus (L.), caused by Streptococcus agalactiae - J. Fish Dis. 37: 757-763.

Najiah M., Aqilah N.I., Lee K.L., Khairulbariyyah Z., Mithun S., Chowdhury A.J.K., Nadirah M. 2012 - Massive mortality associated with Streptococcus agalactiae infection in cage-cultured red hybrid tilapia Oreochromis niloticus in Como River, Kenyir Lake, Malaysia - J. Biol. Sci. 12: 438-442.

Nguyen H.T., Kanai K., Yoshikoshi K. 2002 - Ecological investigation of Streptococcus iniae isolated in cultured Japanese Flounder, Paralicthys olivaceus using selective isolation procedure - Aquaculture 205: 7-17.

OIE 2013 - Aquatic Animal Health Code. 16 ${ }^{\text {th }}$ edition World Organisation for Animal Health, Paris, France, $284 \mathrm{p}$.

Presnell J.K., Schreibman M. 1997 - Humason's animal tissue techniques. $5^{\text {th }}$ edition - Johns Hopkins University Press, Baltimore, MD, 572 p.

Robinson J.A., Meyer F.P. 1966 - Streptococcal fish pathogen - J. Bacteriol. 92: 512. 
Shahi N., Mallik S.K., Pandey J., Chandra S. 2014 - Report of Lactococcus garvieae infection from rainbow trout farms of India - http://www.ncbi.nlm.nih.gov/nuccore/ KM604704.1 (accessed on 22.10.15).

Suanyuk N., Kong F., Ko D., Gilbert G.L., Supamattay K. 2008 - Occurrence of rare genotypes of Streptococcus agalactiae in cultured red tilapia Oreochromis sp. and Nile tilapia $O$. niloticus in Thailand-Relationship to human isolates - Aquaculture 284: 35-40.

Tamura K., Stecher G., Peterson D., Filipski A., Kumar S. 2013 - MEGA6: Molecular Evolutionary Genetics Analysis version 6.0 - Mol. Biol. Evol. 30: 2725-2729.
Wang K.Y., Chen D.F., Huang L.Y., Lian H., Wang J., Xiao D., Geng Y., Yang Z.X., Lai W.M. 2013 - Isolation and characterization of Streptococcus agalactiae from Nile tilapia Oreochromis niloticus in China - Afr. J. Microbiol. Res. 7: 317-323.

Zamri-Saad M., Amal M.N.A., Siti-Zahrah A. 2010 - Pathological changes in red tilapias (Oreochromis spp.) naturally infected by Streptococcus agalactiae - J. Comp. Pathol. 143: 227-229.

Zhang X.Y., Fan H.P., Zhong Q.F., Zhuo Y.C., Lin Y., Zeng Z.Z. 2008 - Isolation, identification and pathogenicity of Streptococcus agalactiae from tilapia - J. Fish. China 32:772-779. 